\title{
Article \\ Redetermination of the Zalantun Group in the ARong Qi Area of Da Hinggan Mountains (Northeastern China): Evidence from Petrology, Geochronology and Geochemistry
}

\author{
Datian $\mathrm{Wu} \mathbf{u}^{1,2,3}$, Zhumin $\mathrm{Li}{ }^{2,3, *}$, Junchao $\mathrm{Lv}^{2,3}$, Jia $\mathrm{Xu}^{2,3}$ and Guanglong Shu ${ }^{2,3}$ \\ 1 School of Earth Sciences and Resources, China University of Geosciences, Beijing 100083, China; \\ wudatian@mail.cgs.gov.cn \\ 2 Shenyang Center, China Geological Survey, Shenyang 110034, China; lvjunchao@mail.cgs.gov.cn (J.L.); \\ sionsega@163.com (J.X.); shuguanglong@mail.cgs.gov.cn (G.S.) \\ 3 Shenyang Institute of Geology and Mineral Resources, Shenyang 110034, China \\ * Correspondence: lizhumin@mail.cgs.gov.cn
}

check for

updates

Citation: Wu, D.; Li, Z.; Lv, J.; Xu, J.;

$\mathrm{Shu}, \mathrm{G}$. Redetermination of the

Zalantun Group in the ARong Qi

Area of Da Hinggan Mountains

(Northeastern China): Evidence from

Petrology, Geochronology and

Geochemistry. Minerals 2022, 12, 197.

https://doi.org/10.3390/

$\min 12020197$

Academic Editors: Sergei Khromykh and Andrei Tsygankov

Received: 5 December 2021

Accepted: 29 January 2022

Published: 3 February 2022

Publisher's Note: MDPI stays neutral with regard to jurisdictional claims in published maps and institutional affiliations.

Copyright: (C) 2022 by the authors. Licensee MDPI, Basel, Switzerland. This article is an open access article distributed under the terms and conditions of the Creative Commons Attribution (CC BY) license (https:// creativecommons.org/licenses/by/ $4.0 /)$.

\begin{abstract}
The Da Hinggan Mountains are an important area in the tectonic evolution of the Central Asian Orogenic Belt (CAOB), and there are disputes over the closure time of the Paleo-Asian Ocean and the amalgamation spatiotemporal relationship between the Ergun-Hinggan Massif and the Songnun Massif. The geochronology and geochemistry of the Late Cambrian-Late Silurian volcanic rock assemblages in the ARong Qi area at the eastern margin of the Da Hinggan Mountains are studied in this paper. The results suggest that the U-Pb zircon ages of the Late Cambrian, Late Ordovician and Late Silurian volcanic rock assemblages are 507.5 $\pm 1.0 \mathrm{Ma}, 456.2 \pm 1.0 \mathrm{Ma}, 446.1 \pm 0.95 \mathrm{Ma}$ and 423.3 — 1.4 Ma, respectively. The Late Cambrian-Late Silurian volcanic rocks are quasi-aluminousperaluminous, belonging to calc-alkaline-shoshonite series, which is rich in HREE but has insignificant europium anomalies. There are abundant large ion lithophile elements (LILE) in the rock, and remarkable $\mathrm{Nb}$, Ta and Ti negative anomalies. The previous data and the current study indicate that a continental margin arc tectonic setting existed in the ARong Qi-Zalantun region during the Early Paleozoic, which is inferred to be the product of the subduction-accretion-amalgamation of the plates along the eastern margin of the Ergun Massif during the Early Paleozoic.
\end{abstract}

Keywords: eastern margin of the Da Hinggan Mountains; Early Paleozoic; Late Cambrian-Late Silurian volcanic rock; $\mathrm{U}-\mathrm{Pb}$ chronology; geochemistry; tectonic setting

\section{Introduction}

With the deep-going studies on Northeast China and the accumulation of some geochemical and isotopic test data, it is generally accepted that several micro-terranes and multiple convergence belts form the basic geotectonic pattern of Northeast China. However, the delineation of the microplates in the northeastern region is still controversial. Previous studies hold that the Ergun Massif and the Hinggan Massif merge along the Tayuan-Xijiatu Fault, and the Late Paleozoic Ergun-Hinggan Massif and the Jiamusi-Songnen Massif amalgamate along the Hegen Mountain-Nenjiang River-Heihe River area [1-9]. The volcanic rocks in the Da Hinggan Mountains have been considered as Mesozoic medium-acidic volcanic rocks [10-15]. The Paleozoic especially Early Paleozoic volcanic rocks, mostly Ordovician volcanic rocks and granitic amphibolites, are less exposed, and their magmatic activities are concentrated in the Duobaoshan area, east of the Hinggan [16-18].

For a long time, the Zalantun Group, west of ARong Qi, has been considered a Paleoproterozoic metamorphic series, representing the Precambrian basement of the Hinggan and Ergun Massifs. There are scholars who have measured the SHRIMP zircon U-Pb age of the Zalantun Group chlorite schist (a type of metabasic volcanic rock), finding that the age was $506 \pm 3 \mathrm{Ma}$. This age range suggests that the Zalantun Group emerged in the 
Late Cambrian and that it is a volcanic-sedimentary formation on the active continental margin [19]. In recent years, during a field geological expedition in the ARong Qi area in the middle part of the Da Hinggan Range, the authors discovered, for the first time, a Late Cambrian-Late Silurian volcanic rock assemblage, the tectonic setting of which is controversial due to the lack of precise geochronological and systematic geochemical studies. In view of this, the authors conducted geochronological and geochemical studies on the Late Cambrian-Late Silurian volcanic rock assemblages in the ARong Qi area. In combination with the regional geological background, the authors probed into the source zone, genesis type, tectonic background and formation mechanism of volcanic rocks in the regional geological context. The authors further investigated the closure process of the Paleo-Asian Ocean and the amalgamation characteristics of the Ergun-Hinggan Massif and the Songnun Massif, aiming to provide basic information for studies on the tectonic pattern and evolution of the eastern part of the Mongolia-Hinggan Orogen.

\section{Regional Geological Background}

In terms of geotectonic location, the Da Hinggan Range is situated east of the MongoliaHinggan Orogen, and the Paleozoic is mainly characterized by the process of multi-phase subassemblage between several micro-landmasses consisting of the Ergun, Hinggan and Songnen Massifs from north to south [9]. The study area is located in ARong Qi, north of the Greater Khingan Range, adjoining the Zalantun-Nenjiang suture zone. The study area tectonically belongs to the Ergun-Hinggan Massif and is located next to the Songnen Massif in the south (Figure 1a), where the Paleozoic volcanic-sedimentary formation and the Mesozoic volcanic rock formation were developed (Figure 1b). Due to multi-subduction in the Paleo-Asian Ocean, the Paleozoic Greater Khingan Range developed arc magmatic rock, ophiolite and accretionary $[20,21]$. The Paleo-Asian Ocean came into being closure during the late Permian-early Triassic [2,22,23], with continental molasse, intermediate volcanic rock formation and early middle Jurassic coal-bearing basins featuring near eastwest distribution. The eastern part of the middle Triassic Central Asian orogenic belt entered the intracontinental extension stage. The Mongol-Okhotsk Ocean closure during the middle-late Jurassic resulted in the uplift and erosion of the northern Greater Khingan Range, as well as the lacuna during the late-Jurassic [24]. The oblique subduction of the western Pacific Plate during the early Cretaceous generated large-scale northward strike-slips, extending depressions and large-scale volcanic activities in eastern China.

The Paleozoic types of rock include primarily Late Cambrian volcanic rock (initially defined as the Zalantun Complex), Late Ordovician volcanic rock (initially defined as the Zalantun Complex) and Late Silurian volcanic rock (initially defined as the Zalantun Complex). The complex is lithologically composed of metamorphic trachybasalt, metamorphic basaltic trachyandesite, metamorphic andesite, metamorphic dacite, metamorphic volcanic clastic rock, etc. Late Cambrian-Late Silurian volcanic rock, mostly existing as mélange, is the first of its kind found in the region. The Mesozoic is dominated by the Upper Triassic Hadataulegai Formation (224.3 $\pm 0.71 \mathrm{Ma})$, with lithologic assemblages of (metamorphic) andesite, metamorphic pelitic siltstone and silty mudstone; the Middle-Upper Jurassic Tamulangou Formation (158.58 $\pm 0.46 \mathrm{Ma})$, chiefly composed of gray-black compacting and blocky basalt and dolerite with a handful of dark gray andesite; the Lower Cretaceous Baiyingaolao Formation (139.80 $\pm 0.57 \mathrm{Ma})$, primarily comprising acidic lava and volcanic clastic rocks, with main lithologies being rhyolite, andesite and rhyolitic brecciated crystal tuff, rhyolitic brecciated vitric tuff, acidic welded crystal tuff, acidic tuff, etc.; the Longjiang Formation (124.67 $\pm 0.47 \mathrm{Ma})$, with the lithologic assemblage of grayish purple, grayish green and dark gray andesite, and andesitic tuff, sandwiched between tuffaceous sandstone and bedded tuff; the Guanghua Formation (123.89 $\pm 0.45 \mathrm{Ma})$, comprising rhyolitic brecciated crystal tuff, rhyolitic breccia-bearing vitric tuff, rhyolitic welded fiamme-vitriccrystal tuff, acidic welded crystal tuff, tuffaceous fine sandstone, tuffaceous glutenite, etc.; the Jiufengshan Formation (clastic zircon $119.74 \pm 0.28 \mathrm{Ma}$ ), whose lithologic assemblage includes tuffite, tuffaceous sandstone and tuffaceous glutenite; and the Ganhe Formation, 
which is composed of porous amygdaloidal basalt, compacting and blocky basalt, and bits of basaltic clastic rocks. Magmatic intrusions are shown from the Early Jurassic to the Early Cretaceous, with the Late Jurassic intrusive rocks being the most developed. There are developed fractures in the study area, mostly in the NE and NW directions, and the approximately EW, approximately NS and NNE fractures are complementary to each other and present a net-like tectonic framework. In the Pre-Mesozoic epoch, the EW-extended ductile shear zone was developed, and the Paleozoic geological bodies cut by this zone were intruded by post-Paleozoic geological bodies along the fault zone and cut and destructed by late-stage faults. The Mesozoic epoch is represented by Yanshan brittle fractures, which largely modify the pre-existing tectonics and give rise to a NE-oriented spreading volcanic rifted basin. Mesozoic brittle fracture activities have basically established the present-day geomorphic pattern in the survey area [17].

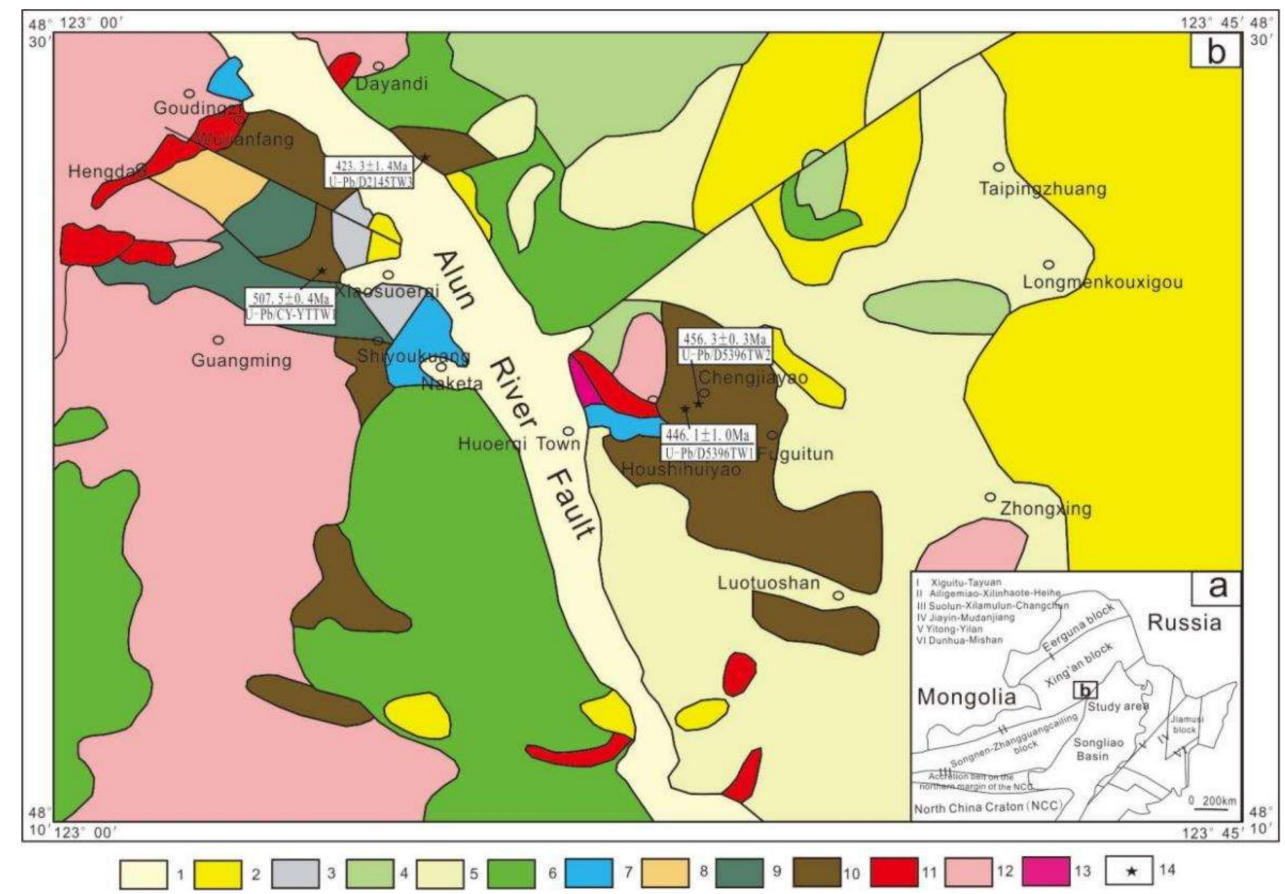

Figure 1. Geological sketch map of the studied area. 1. Quaternary, 2. Ganhe Formation, 3. Jiufengshan Formation, 4. Guanghua Formation, 5. Baiyingaolao Formation, 6. Longjiang Formation, 7. Tamulangou Formation, 8. Hadataulegai Formation, 9 Linxi Formation, 10. Cambrian-Silurian tectonic mélange, 11. Early Cretaceous intrusive rocks, 12. Late Jurassic intrusive rocks, 13. Middle Jurassic intrusive rocks, 14. Location and results of Isotope samples. (a) Geotectonic location of the ARong Qi, Da Hinggan Mountains (Northeastern China), (b) Simplified geological map of the ARong Qi area.

\section{Sample Characteristics}

The locations of the volcanic samples collected are shown in Figure 1b, and the petrographic characteristics are as follows: Samples CY-YTTW1 (G1-G2), D5396TW1 (G3-G5 and G8), D5396TW2 (G6-G7) and D2145TW3 (G9-G10) were collected in the vicinity of Xiaosuoerqi Town and Chenjiayao Village in the $\mathrm{A}^{\prime}$ Rong Qi area, Inner Mongolia (corresponding sampling coordinates: E $123^{\circ} 10^{\prime} 15^{\prime \prime}$, N $48^{\circ} 23^{\prime} 55^{\prime \prime}$; E $123^{\circ} 24^{\prime} 06^{\prime \prime}$, N $48^{\circ} 20^{\prime} 41^{\prime \prime}$; E $123^{\circ} 24^{\prime} 05^{\prime \prime}$, $\mathrm{N} 48^{\circ} 20^{\prime} 42^{\prime \prime}$; E $123^{\circ} 14^{\prime} 08^{\prime \prime}$, N 48 $26^{\prime} 42^{\prime \prime}$ ). Samples CY-YTTW1 and D5396TW1 are andesites with a massive structure and a blastoporphyritic texture, and the phenocryst is chiefly composed of plagioclase. The matrix is a cryptocrystalline structure. The rocks underwent carbonate alteration (Figure 2a,b). Sample D5396TW2 is a metamorphic andesites with a massive structure and a blastoporphyritic texture (Figure 2c,d). Sample D2145TW3 is a piece of blocky and porphyritic andesite, and the phenocryst is primarily composed of plagioclase, whereas the matrix has an andesitic structure. 

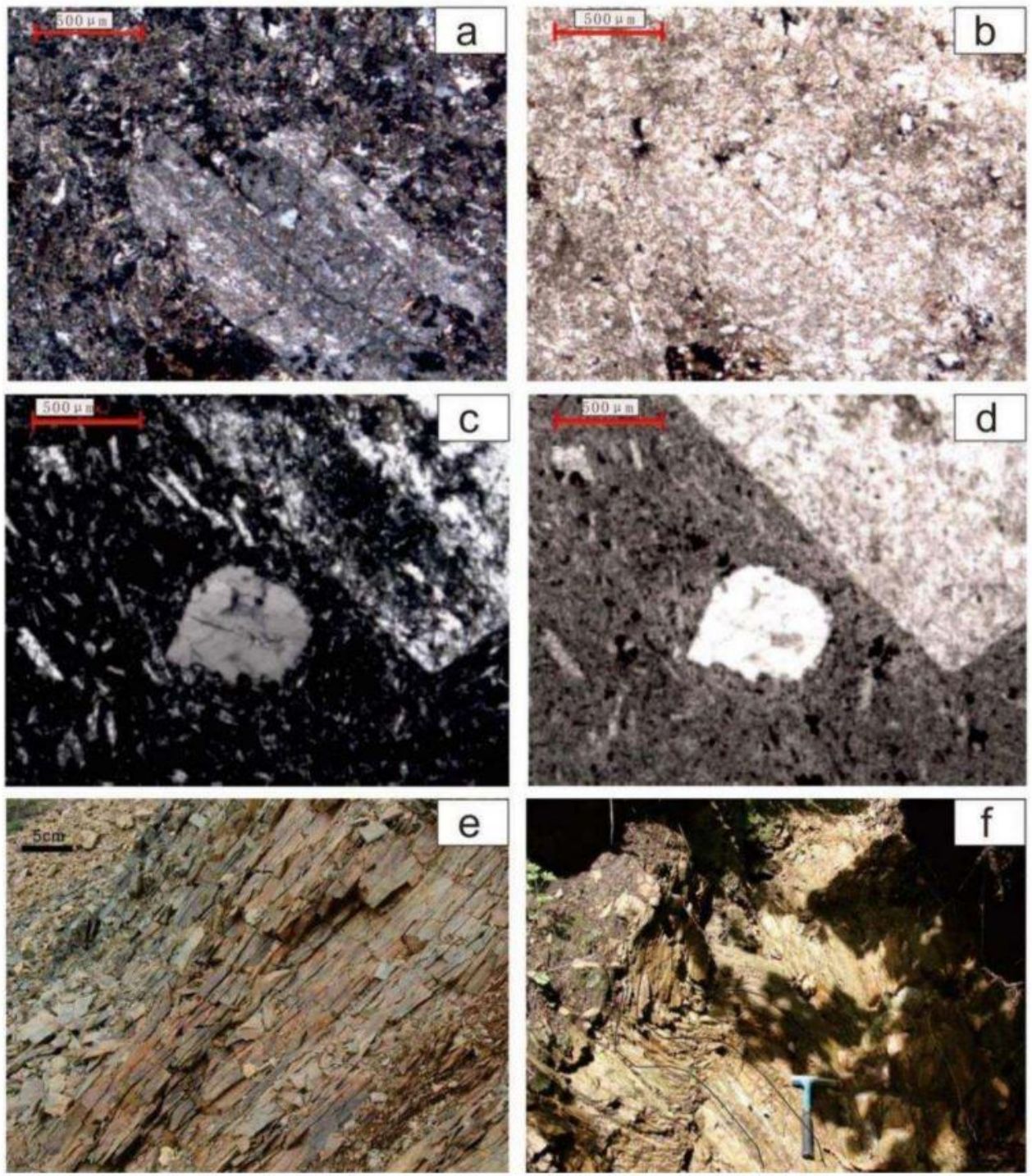

Figure 2. Field and microscopic photomicrographs of Late Cambrian-Late Silurian volcanic rocks. $(\mathbf{a}, \mathbf{b})$ Orthogonal polarization of andesite with carbonated alterations, $(\mathbf{c}, \mathbf{d})$ orthogonal polarization of metamorphic rhyolite with a variable porphyritic structure, (e) mylonite foliation, (f) fold deformation.

\section{Analytical Method}

\subsection{Zircon LA-ICP-MS U-Pb Dating}

Sample crushing and zircon separation were performed in the laboratory at the Hebei Regional Geological Survey Institute (Langfang, China). Zircon was separated using an electromagnetic method, and typical and transparent zircon particles in a good crystal shape and free of cracks and inclusions were sorted to create sample targets as described in relevant literature [25]. The transmission and reflection electron images and cathodoluminescence (CL) images of zircon (Figure 3) were analyzed before running the zircon $\mathrm{U}-\mathrm{Pb}$ test, and the dating points were calibrated according to the crystal morphology and internal structures of zircon particles. The zircon laser-exfoliation plasma mass spectrometry (LA-ICP-MS) U-Pb dating of volcanic samples was performed by the Beijing Yandu Zhongzhi Testing Technology Co. The Bruker M90 was the inductively coupled plasma mass spectrometer (ICP-MS) aided by a New Wave 193-FXArF (New Wave Up 213) laser ablation system was the equipment chosen for this experiment. A laser beam spot with a diameter of $25 \mu \mathrm{m}$, a frequency of $10 \mathrm{~Hz}$ and an energy density of about $2.5 \mathrm{~J} / \mathrm{cm}^{2}$ was chosen, and He was used as carrier gas. The ordinary lead was calibrated as previously described by Andersen [26]. Isotopic fractionation correction was performed using zircon 
standards GJ-1 and 91500 and Plesovice as external standards. GJ-1 was analyzed twice for every 5-10 sample points, and t zircon trace element content was quantified by the SRM610 as the external standard and $\mathrm{Si}$ as the internal standard. Laboratory test details can be found in related literature [27]. Age calculations were performed using the international standard program Ispplot (version 3.0). The error was $1 \sigma$ for both the test data and weighted mean ages. For the zircon tested younger than $1000 \mathrm{Ma}$, the ${ }^{206} \mathrm{~Pb} /{ }^{238} \mathrm{U}$ age was adopted to filter the $\mathrm{U}-\mathrm{Pb}$ age data by the ratio of the ${ }^{206} \mathrm{~Pb} /{ }^{238} \mathrm{U}$ age to the ${ }^{207} \mathrm{~Pb} /{ }^{206} \mathrm{U}$ age [28-31], and the data with a concordance degree of $95 \%$ or above were considered valid.

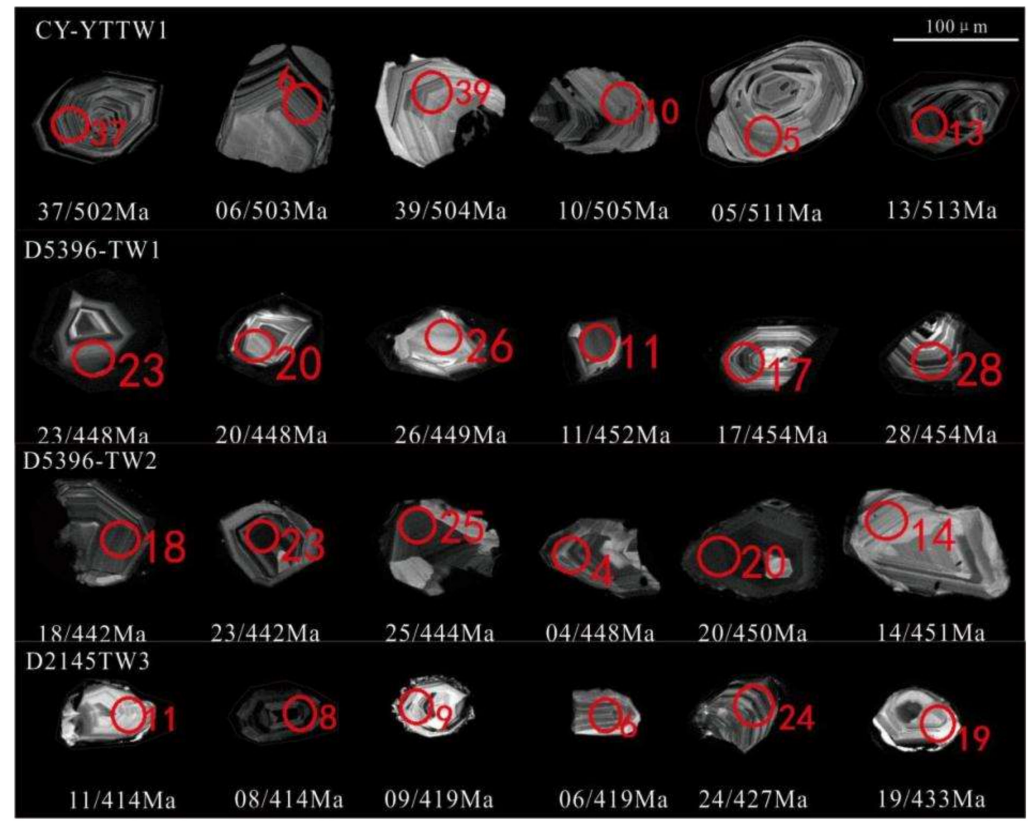

Figure 3. CL images of representative zircons from the Late Cambrian-Late Silurian volcanic rocks in the A'Rong Qi area.

\subsection{Whole-rock Primary and Trace (Rare Earth) Elements}

In this paper, nine volcanic rock samples were tested for primary and trace (rare earth) elements, and samples testing was performed at the Northeast Mineral Resources Supervision and Testing Center of the Ministry of Land and Resources. After the thin sections from the collected samples were identified by microscopy, the samples were selected for geochemical analysis, which was entirely conducted in a pollution-free facility. The primary elements were tested using X-ray fluorescence spectrometry (XRF) and other methods (FeO by chemical titration, loss-on-ignition by chemical mass analysis). In addition, rare earth elements La, Ce, Pr, Nd, Sm, Eu, Gd, Tb, Dy, Ho, Er, Tm, Yb, Lu and Y, as well as trace elements Th, U, Ta and Li, were tested by ICP-MS. The precision and accuracy of the primarily elements analyzed were above $5 \%$, and the results for trace elements were generally higher than $10 \%$.

\section{Result Analysis}

\subsection{Zircon LA-ICP-MS U-Pb Dating Results}

5.1.1. Late Cambrian Volcanic Rock Age

CY-YTTW1 (metamorphic andesite): The sample test results are given in Table S1, and the selected zircon grains have a clear internal crystal structure with significant magmatic oscillatory growth rings and high $\mathrm{Th} / \mathrm{U}$ ratios, generally $0.36-1.26$, indicating that the zircon has a magmatic crystallization origin [32]. A zircon U-Pb concordant age of $507.5 \pm 1.0$ (Ma) was obtained (Figure 4), which represents the andesite formation age during the Late Cambrian epoch. The deviated zircon $\mathrm{U}-\mathrm{Pb}$ ages in the table are the ages of captured and nascent zircon. The nascent zircon age is 448.5-483.4 (Ma), implying that magmatic 
hydrothermal events still occurred after rock formation. The captured peritectic zircon ages (548.5-549.4 Ma) indicate the presence of a Precambrian basement in the area.
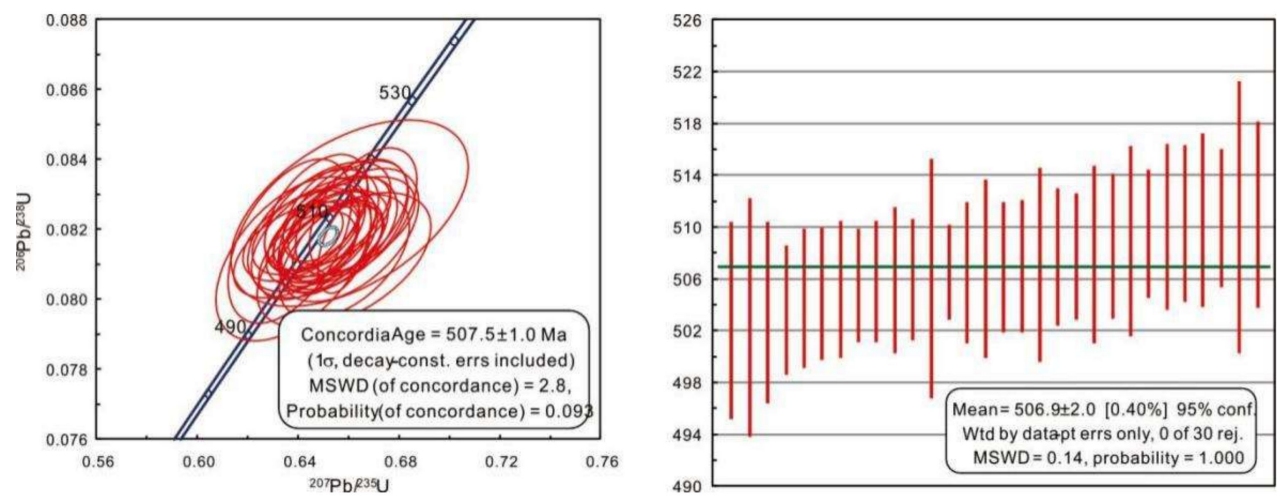

Figure 4. Zircon $\mathrm{U}-\mathrm{Pb}$ isotopic age harmony map of Late Cambrian metamorphic andesite (CY-YTTW1).

\subsubsection{Late-Ordovician Volcanic Rock Age}

D5396TW1 (metamorphic andesite) and D5396TW2 (metamorphic andesite): The test results are shown in Table S1. The internal structure of zircon granular crystals is clear with obvious magmatic oscillatory growth rings and high Th/U ratios (0.40-1.57), suggesting that the zircons are magmatic in origin. The $\mathrm{U}-\mathrm{Pb}$ concordant ages obtained for andesite and zircon are $456.2 \pm 1.0(\mathrm{Ma})$ and $446.1 \pm 0.95$ (Ma) (Figures 5 and 6), representing andesite formation in the Late Ordovician.
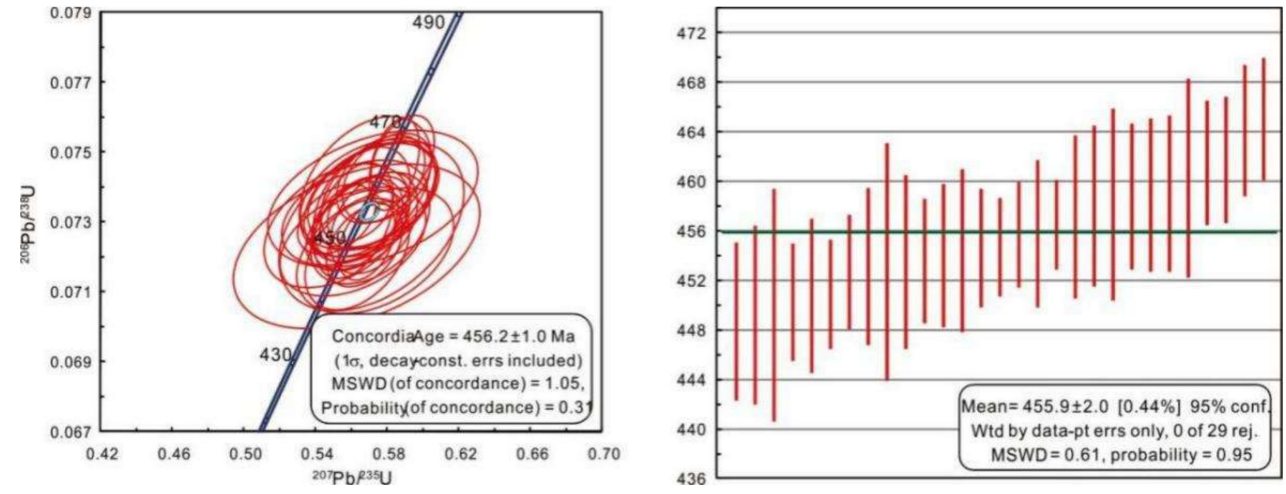

Figure 5. Harmony diagram of $\mathrm{U}-\mathrm{Pb}$ isotopic ages of zircon from the Late Ordovician metamorphic andesite (D5396TW1).
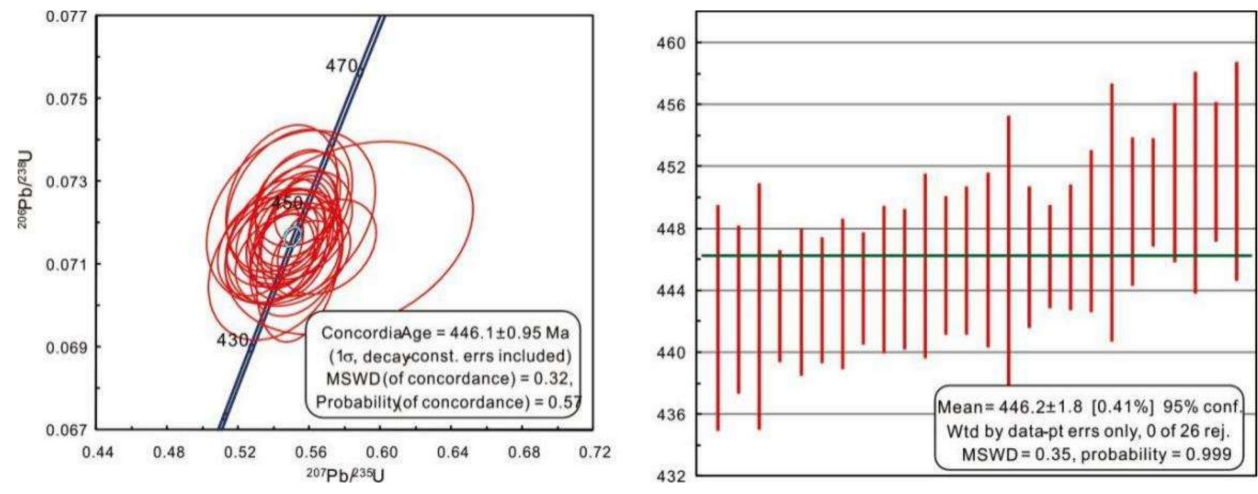

Figure 6. Harmony diagram of $\mathrm{U}-\mathrm{Pb}$ isotopic ages of zircon from the Late Ordovician metamorphic andesite (D5396TW2). 


\subsubsection{Late-Silurian Volcanic Rock Age}

D2145TW3 (andesite): Zircon grains feature clear internal crystal structures, notable magmatic oscillatory growth rings and high $\mathrm{Th} / \mathrm{U}$ ratios, generally $0.41-1.92$, indicating that the zircon is magmatic in origin. Two groups of zircon $\mathrm{U}-\mathrm{Pb}$ concordant ages, namely $423.3 \pm 1.4(\mathrm{Ma})(n=12)$ and $510.8 \pm 2.0(\mathrm{Ma})(n=6)$, were calculated (Figure 7$)$, the former representing Late Silurian andesite and the latter the captured zircon. The zircon ages of the deviated group are 537.2-1450.5 (Ma), which is the age of magma-captured peritectic zircon.
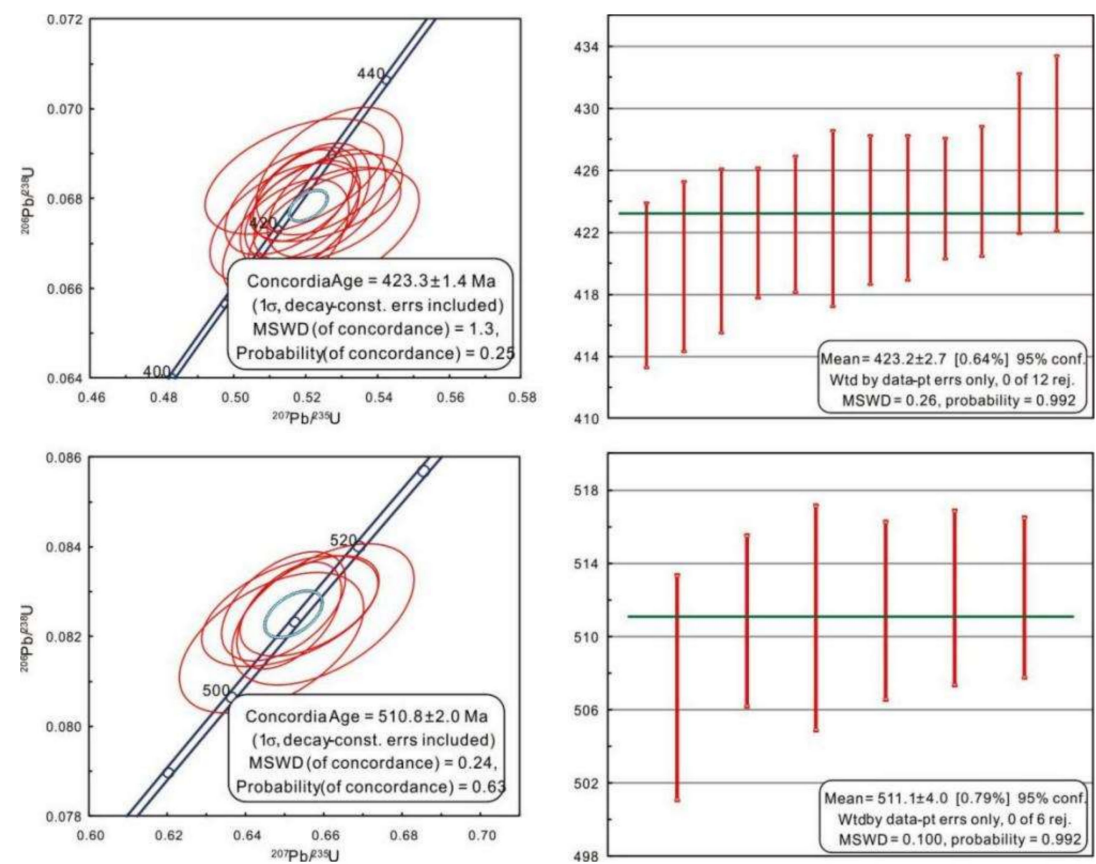

Figure 7. Harmony diagram of $\mathrm{U}-\mathrm{Pb}$ isotopic ages of zircon from the Late Silurian andesite (D2145TW3).

\subsection{Primary and Trace Element Characteristics}

Two Late Cambrian volcanic rock samples, six Late Ordovician volcanic rock samples and Late late Silurian volcanic rock samples were collected. Table S2 shows the analyses of the primary and trace elements comprising the samples. The Late Cambrian volcanic rock samples are G1-G2, the Late Ordovician volcanic rock samples are G3-G8 and the Late Silurian volcanic rock sample is G9-G10. As most of the samples exhibited a loss on ignition (LOI) greater than $1.5 \%$, the TAS classification diagram does not apply to the volcanic rock samples. In this paper, inactive high-field strength elements (HFSEs, like Ti, $\mathrm{Zr}, \mathrm{Nb}, \mathrm{Ta}, \mathrm{Hf}$ and $\mathrm{Y}$ ) and rare earth elements (REEs) were the elements primarily used for lithological classification and discussions of tectonic setting and lithogenesis.

\subsubsection{Primary Elements}

The LOI is high and linked to later volcanic rock alterations to varying degrees which caused increases in sample volatiles. Late Cambrian-Late Silurian volcanic rock showed major changes in primary elements, which can be reconverted on a percentage basis after LOI subtraction. It is shown that the Late Cambrian-Late Silurian volcanic rock samples exhibited a major $\mathrm{SiO}_{2}$ content change (52.56-62.79\%). The total alkali $\left(\mathrm{Na}_{2} \mathrm{O}+\mathrm{K}_{2} \mathrm{O}\right)$ change was at a medium level (5.70-8.92\%; mean: $7.79 \%)$, the total ion change $\left(\mathrm{FeO}^{*}\right)$ was $4.17-6.38 \%$ with a $6.15 \%$ mean, the $\mathrm{MgO}$ content change was $0.08-0.28 \%$ with a $0.20 \%$ mean and a $2.14-8.09 \% \mathrm{Mg}$, and the $\mathrm{TiO}_{2}$ content change was $0.47-1.71 \%$ with a mean $(0.89 \%)$, similar to that of calc-alkaline andesite [33]. In the diagram showing $0.0001 \times \mathrm{Zr} / \mathrm{TiO}_{2}-\mathrm{Nb} / \mathrm{Y}$, the Late Cambrian-Late Silurian volcanic rock samples were taken 
from andesitic or basaltic strata and proved to be consistent with microscopic examination findings (Figure 8a). In the diagram showing Th-Co, the samples were primarily projected in the calc-alkaline series, and a few fell into the high-potassium calc-alkaline series and the peridotitic trachybasalt series (Figure $8 b$ ).
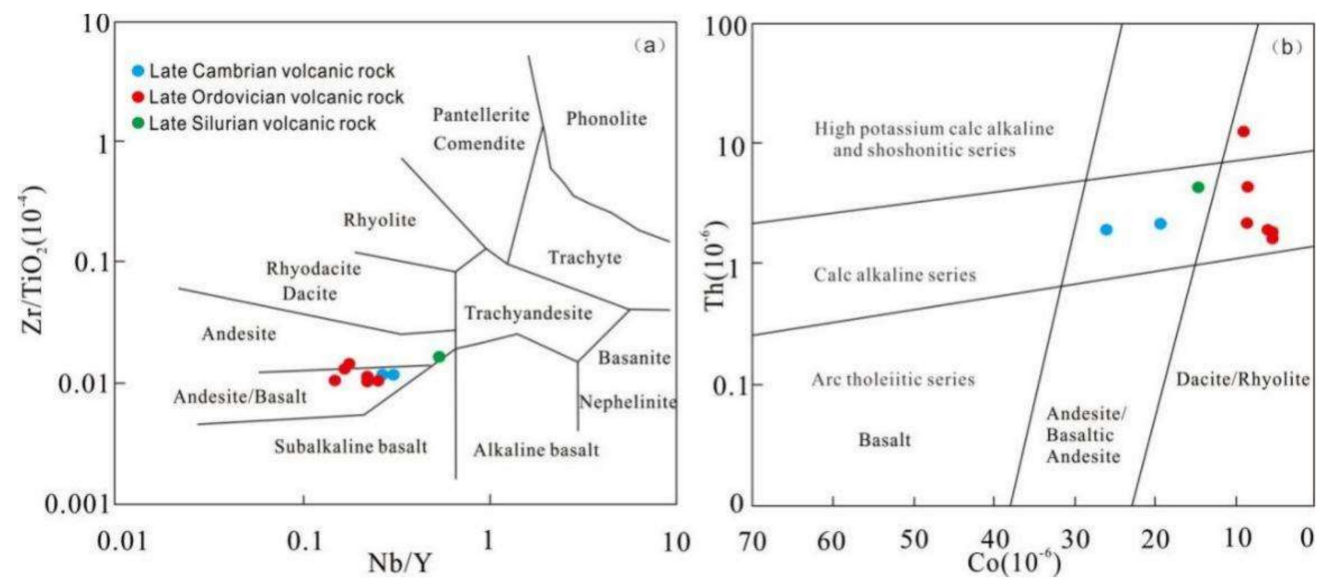

Figure 8. (a) $0.0001 \times \mathrm{Zr} / \mathrm{TiO}_{2}$ vs. $\mathrm{Nb} / \mathrm{Y}$ diagram (after [34] and (b) Th vs. Co diagram (after [35] for the Late Cambrian-Late Silurian volcanic rocks in the A'Rong Qi area.

\subsubsection{Trace (Rare Earth) Element Characteristics}

The analysis results for rare earth elements are shown in Table S2. The total rare earth in the Late Cambrian-Late Silurian volcanic rocks is $\sum R E E=(70.87-181.23) \times 10^{-6}$ with an average of $132.73 \times 10^{-6}$, which is much lower in intermedium-basic rocks than in acidic rocks. The LR/HR ratios of light and heavy rare earths are 5.37-11.55 (mean value 7.10), and the $(\mathrm{La} / \mathrm{Yb})_{\mathrm{N}}$ is 3.74-15.74, suggesting the light rare earth was enriched. The fractionation of light and heavy rare earths was remarkable, and the intermediate-basic rocks have a high degree of it. $(\mathrm{La} / \mathrm{Sm})_{\mathrm{N}}$ is $2.00-3.11$, and $(\mathrm{Gd} / \mathrm{Yb})_{\mathrm{N}}$ is $1.09-2.87$. The light rare earths were more fractionated than their heavier counterparts, and the degree of fractionation was high in alkaline rocks. $\delta \mathrm{Eu}$ is $0.82-1.18$, and the $\mathrm{Eu}$ anomaly was not obvious. The standardized fractionation curves of the rare earth element chondrite meteorite were basically identical, both asymmetrically leaning to the right (Figure 9a). The rare earth element types of all rock samples are similar to the elemental composition characteristics of the Ocean Island Basalt (OIB) [36] (Figure 9a), indicating that the Late Cambrian-Late Silurian volcanic rocks may have originated from the fertile mantle area of the OIB and underwent the same magmatic evolutionary process.
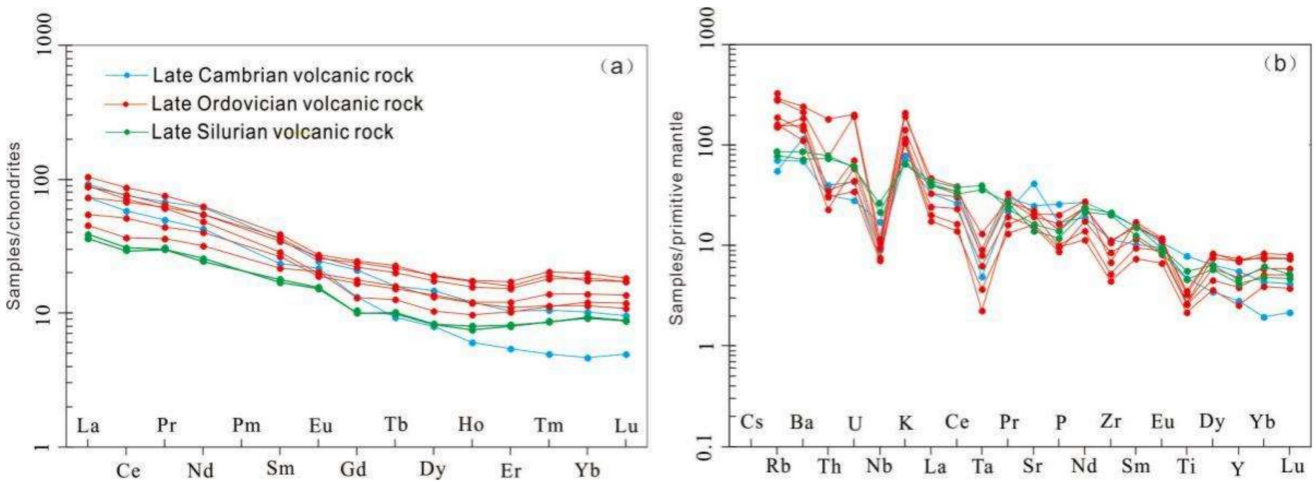

Figure 9. (a) Distribution patterns of rare earth elements and (b) trace element cobweb map of Late Cambrian-Late Silurian volcanic rocks with a standardized data quote from [37].

The general high field strength elements (HFSE) Nb, Ta and Ti showcase obvious negative anomalies, and $\mathrm{Th}$ and $\mathrm{U}$ are relatively enriched in the primitive mantle-normalized 
spider chart of trace elements. The large ion-lithophile (LIL) elements $\mathrm{Rb}, \mathrm{Ba}, \mathrm{K}$ and $\mathrm{Sr}$ are relatively enriched (Figure $9 b$ ). Sr and $\mathrm{K}$ have the largest distribution coefficients in plagioclase, and their depletion may be associated with the fractional crystallization of plagioclase.

\section{Discussion}

\subsection{Age of Early Paleozoic Volcanic Rock Formations in the Study Area}

According to the 2005 geological survey report at a 1:250,000 scale on the topographic map of the A'Rong Qi area issued by the third geological team from the Qiqihar Branch of the Heilongjinag General Institute of Ecological Survey and Research and the latest data, the Zalantun Group in the western part of A'Rong Qi in the study area has long been considered a Paleoproterozoic metamorphic series representing the Precambrian basement of the Hinggan and Ergun Massifs. Moreover, its formation age has always been prioritized when it comes to research and is a point of contention in this area. Scholars measured the SHRIMP zircon U-Pb age of the Zalantun Group chlorite schist, which is (506 \pm 3 ) Ma, suggesting that the Zalantun Group emerged in the Late Cambrian, and it is a volcanicsedimentary formation on the active continental margin [19]. The $507.5 \pm 1.0$ (Ma) zircon $\mathrm{U}-\mathrm{Pb}$ of the metamorphic andesite measured in the $\mathrm{A}^{\prime}$ Rong Qi area is highly consistent with the chloritic schist (metabasic volcanic rocks) age of the Zalantun Group, demonstrating that they are products of coeval magmatic activities and may have formed in the same tectonic setting, albeit with different degrees of deformation and metamorphism. The zircon ${ }^{206} \mathrm{~Pb} /{ }^{238} \mathrm{U}$ age of Paleozoic volcanic rocks is $423.3-507.5 \mathrm{Ma}$ in the A'Rong Qi area, falling to the age of 427-563 Ma among the upper metavolcanic rocks of the Dawangzi Formation in the Wolegen terrain in the Xinlin area, north of the Greater Khingan Mountains [38], which may reflect coeval volcanism in two different areas under the Paleo-Asian Ocean tectonic regime. The aforementioned data suggest that the Early Paleozoic volcanic rocks in the A'Rong Qi area are, in fact, an assemblage of rock strata spanning from the Cambrian to the Early Silurian.

\subsection{Petrogenesis and Tectonic Settings}

Calc-alkaline andesite occurs as an integral part of orogenic belts. Studying its origination plays a key role in revealing crust formations and development, as well as crust-mantle interactions [39]. The popular theories surrounding calc-alkaline andesite formation include the partial melting of the crust due to the underplating of the mantle-derived basaltic magma [40-42], fractional crystallization of mantle-derived magma [43,44], migmatization of crust-derived felsic magma and mantle-derived basaltic magma [45,46] and partial melting of the metasomatic mantle wedges of the subduction-induced fluids or fusion [47-49]. The samples of the Late Cambrian-Late Silurian volcanic rock (mostly andesite) collected from the region of interest have a high LOI (1.68-7.31), suggesting deuteric alterations to some degree. Nevertheless, the content of the primary elements in the volcanic rock samples does not significantly change as LOI increases. A prominent linear correlation exists between $\mathrm{Zr}$ and REEs, HFSE (e.g., Ti, $\mathrm{Zr}, \mathrm{Nb}$ and $\mathrm{Hf}$ ) and large ion lithophile elements (LILEs, such as $\mathrm{Rb}, \mathrm{Ba}$ and $\mathrm{Sr}$ ), which indicates that the primary and trace elements in andesite-predominated volcanic rock did not migrate to a significant degree. This can serve as an important basis for studying the volcanic rock genesis and lithological features of the source region.

The geochemical characteristics of Late Cambrian-Late Silurian volcanic rocks indicate that the magma primarily came from the upper mantle or lower crust with intrusions of continental crust substances. The $\mathrm{Nb} /$ Ta ratios of rock range from 6.10 to 33.88 with a mean value of 15.56, similar to the mantle mean (17.5) [37] and higher than the crustal mean (about 11) [50]. The $\mathrm{Zr} / \mathrm{Hf}$ ratio mostly ranges from 16.75 to 46.65 with a mean value of 30.60 , similar to the mantle mean (30.74) [50] but much lower than the crustal mean (44.68) [51]. The Th/U is $1.57-4.96$, with a mean value of 3.11 , which is lower than the Th/U ratio of the lower crust (about 6) [52]. The rocks are generally a quasi-aluminous-peraluminous 
HREE-rich calc-alkaline-shoshonite series with insignificant europium anomalies. The rocks are rich in $\mathrm{Th}, \mathrm{U}, \mathrm{Rb}, \mathrm{Ba}, \mathrm{K}$ and $\mathrm{Sr}$ and possess significant negative anomalies in $\mathrm{Nb}$, Ta and $\mathrm{Ti}$, indicating that residues from minerals such as ilmenite, rutile and titanite in the magmatic source area, was well as the the intrusion of crust-derived substances. The $\mathrm{Rb} / \mathrm{Sr}$ ratio (0.25 on average) of the rock is similar to the crustal value (0.35) [50] and significantly higher than that of the primitive mantle (0.03), E-MORB (0.033) and OIB (0.047). The high $\mathrm{Rb} / \mathrm{Sr}$ ratio may reflect the enriched mantle source area. The $\mathrm{Mg}^{\#}$ value ranges from 2.14 to 8.09 with an average of 5.63, much lower than the $\mathrm{Mg}^{\#}$ values of primitive magma in equilibrium with mantle peridotites (91.5-93.5), suggesting that the rock was contaminated by continental crust substances during its formation [53] or that magma splitting occurred. In summary, the rocks have the geochemical characteristics of magmatic rocks in a subduction setting [54].

In the Zalantun Complex, the Late Cambrian-Late Ordovician-Late Silurian volcanic rock samples have a low $\mathrm{Sr} / \mathrm{Y}$ ratio and high $\mathrm{Y}$ and $\mathrm{Yb}$ content. In this regard, said rock clearly differs from adakite sourced from plate subductions or lower crust delamination while resembling typical arc volcanic rock. Whereas mantle-derived magma rose to emplace, the crustal matter was unavoidably contaminated [55]. The samples featured evident $\mathrm{Nb}$ and Ta depletion, as well as a large amount of trapped zircon, suggesting possible crustal material contamination. Overall, the volcanic samples have high $\mathrm{K}_{2} \mathrm{O} / \mathrm{P}_{2} \mathrm{O}_{5}$ and $\mathrm{K}_{2} \mathrm{O} / \mathrm{TiO}_{2}$ ratios. At the same time, the ratios have proved to be positively correlated with the $\mathrm{SiO}_{2}$ content (see Figure 10b,c). In the diagram of the $\mathrm{Th} / \mathrm{Yb}$ ratio and the $\mathrm{Ba} /$ La ratio (Figure 10d), the samples generally feature a trend of a subduction-induced metasomatism [56], while some samples exhibit a high $\mathrm{Th} / \mathrm{Yb}$ ratio, suggesting that deposit subductions contributed to the magma source region.
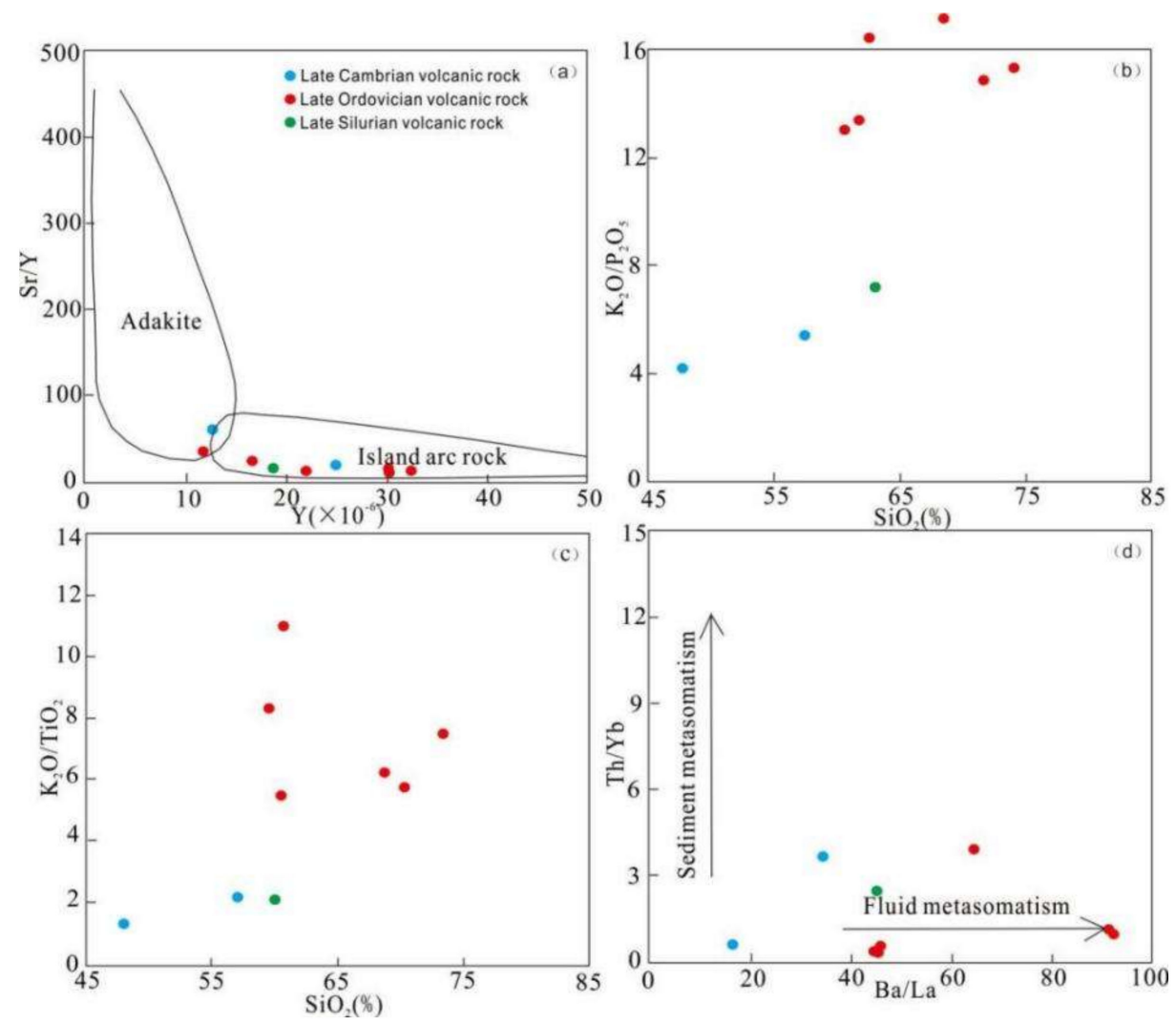

Figure 10. (a) $\mathrm{Sr} / \mathrm{Y}$ vs. $\mathrm{Y}$ diagram (after [57], (b) $\mathrm{K}_{2} \mathrm{O} / \mathrm{P}_{2} \mathrm{O}_{5}$ vs. $\mathrm{SiO}_{2}$ diagram, (c) $\mathrm{K}_{2} \mathrm{O} / \mathrm{TiO}_{2}$ vs. $\mathrm{SiO}_{2}$ diagram, and (d) Th /Yb vs. Ba /La diagram (after [56] for the Late Cambrian-Late Silurian volcanic rocks in the A'Rong Qi area. 
Late Cambrian-Late Silurian volcanic rock in Arong Banner area has high $\mathrm{Nb} / \mathrm{Yb}$ and $\mathrm{Th} / \mathrm{Yb}$ ratios. In the diagram of the $\mathrm{Th} / \mathrm{Yb}$ and $\mathrm{Nb} / \mathrm{Yb}$ ratios, the samples are projected in the continental arc area [17], suggesting that the rock possibly came into being because of subduction from an active continental margin. In the $\mathrm{Ba} / \mathrm{Nb}-\mathrm{La} / \mathrm{Nb}$ diagram, the sample fell into the island arc region (Figure 11a), suggesting that it is associated with arc magmatism. In the $\mathrm{Th} / \mathrm{Yb}-\mathrm{Nb} / \mathrm{Yb}$ diagram, the sample fell within the continental margin arc region (Figure 11b), meaning that it was formed on the convergent plate margin.
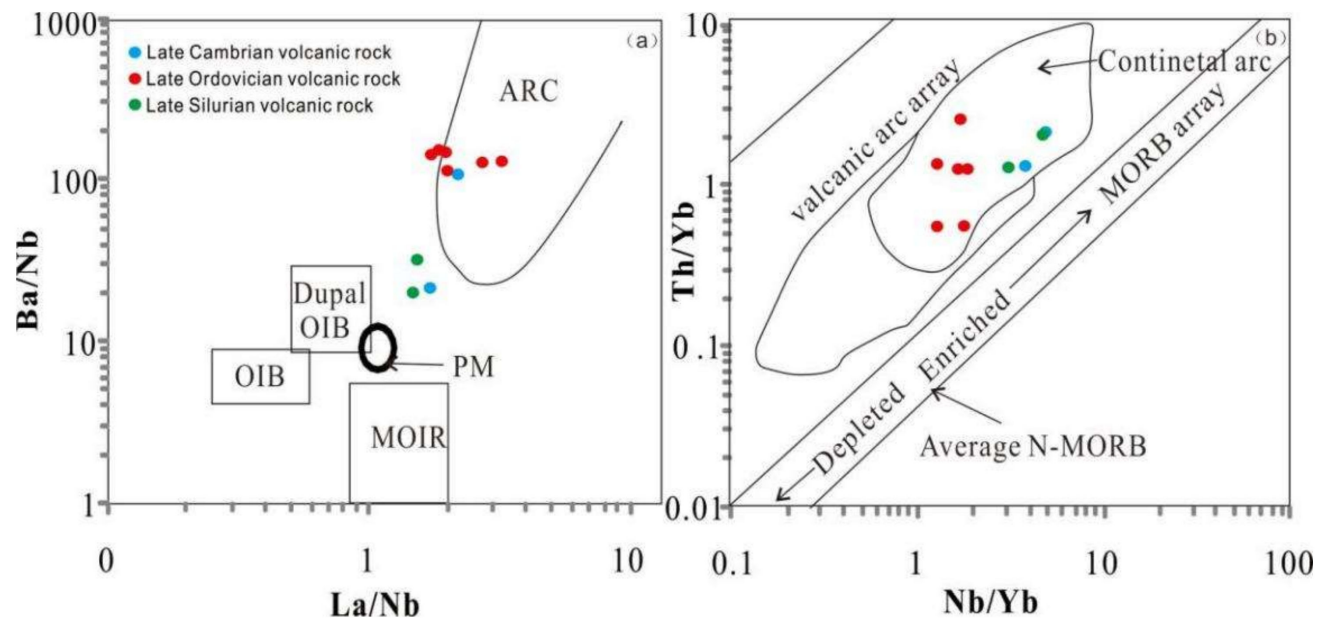

Figure 11. The diagrams of $\mathrm{La} / \mathrm{Nb}-\mathrm{Ba} / \mathrm{Nb}(\mathbf{a})$ (after [58] and $\mathrm{Nb} / \mathrm{Yb}-\mathrm{Th} / \mathrm{Yb}(\mathbf{b})$ volcanic rocks from Late Cambrian to Late Silurian (modified after [59]. ARC = Arc igneous, OIB = ocean island basalt, $\mathrm{MORB}=$ mid-ocean ridge basalt $\mathrm{PM}=$ primitive mantle

As stated above, the aforementioned features indicate that Late-Cambrian-Late Silurian calc-alkaline volcanic rock in the A'Rong Banner area was mantle-derived and tectonically came into being in the marginal continental arc area. Considering the oceanic crustal subduction features of the samples, deposit subduction likely contributed to the source region, which underwent fractional crystallization during magmatic evolution. In addition, based on regional tectonic evolution, the author attributes the genesis of the major Khingan Block to plate subduction-accretion on the eastern margin of the Ergun Block in the Early Paleozoic.

Based on the aforementioned analysis and discussion, this paper has built a model for the Early Paleozoic tectonic evolution of the eastern margin of the Da Hinggan Mountains (Figure 12).

(1) 537-508 Ma: The Paleo-Asian Ocean subducted beneath the Ergun Massif to form a Cambrian arc granite belt on the Ergun Massif. Along with the continuous subductionaccretion and amalgamation of the oceanic crust, the subduction belt continuously retreated into the ocean, and the $508 \mathrm{Ma}$ subduction belt migrated to the southeast side of the Duobaoshan-ARongqi-Zalantun magmatic arc (Figure 12a).

(2) 508-423 Ma: The oceanic basin subduction caused the Duobaoshan-Arongqi-ZalantunYi'ershi magmatic arc, within which Duobaoshan (Mt Duobao) porphyry-type copper ores developed, and extensive Ordovician deposition was present in the back-arc extension area. Massive post-orogenic granites formed on the southern edge of and inside the Ergun Massif, along with lithosphere expansion in the back-arc area (Figure 12b). 
(a) Early Cambrian

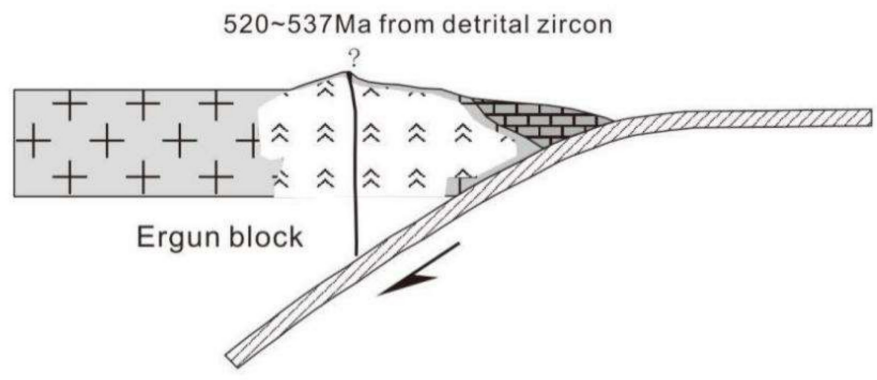

(b) Late Cambrian-Late Silurian

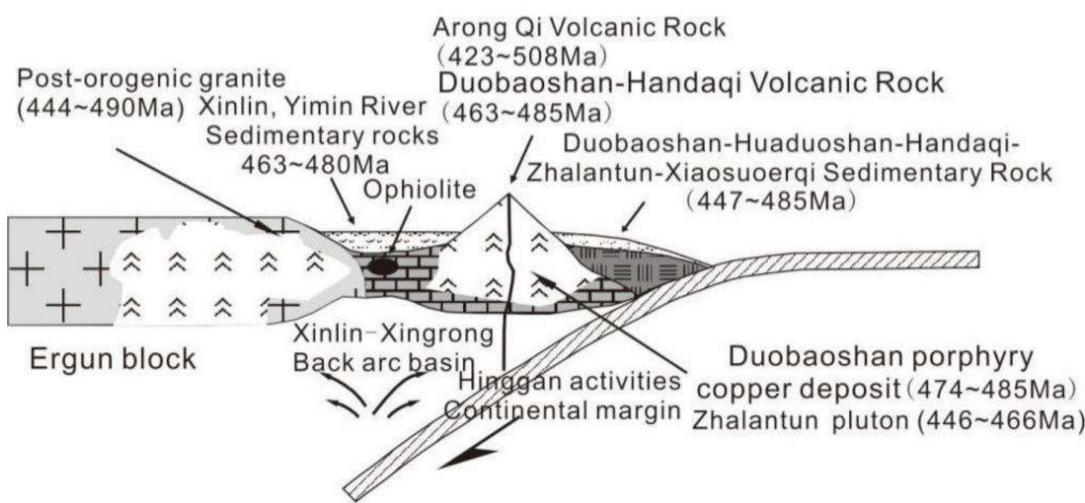

Figure 12. Diagram of the Early Paleozoic tectonic evolution model in the northern Da Hinggan Mountains. The detrital zircon data are quoted from [60]; the post-orogenic granite data are quoted from [61]; the Xinlin and Yimin River sedimentary rocks data are quoted from [5]; the Arongqi volcanic rock data are quoted from this article; and the data of Duobaoshan-Handaqi volcanic rocks are quoted from [38]. The data of Duobaoshan-Huahuashan-Handaqi-Zhalantun-Xiaosuoerqi sedimentary rocks are quoted from $[60,62,63]$. The data of the Duobaoshan porphyry copper deposit are quoted from $[61,64,65]$ The data from the Zhalantun pluton are quoted from [66]. (a) Early Cambrian, (b) Late Cambrian-late Silurian.

\section{Conclusions}

The study on the zircon $\mathrm{U}-\mathrm{Pb}$ geochronology and lithogeochemistry of the Early Paleozoic volcanic rocks in the A'Rong Qi area has led to the following conclusions:

(1) Late Cambrian-Late Silurian volcanic rocks exist in the A'Rong Qi area, and the zircon $\mathrm{U}-\mathrm{Pb}$ isotopic age is $423.3-507.5 \mathrm{Ma}$. The volcanic rocks were identified as a set of rock stratigraphic assemblages spanning from the Late Cambrian to the Early Silurian.

(2) The Late Cambrian-Late Silurian volcanic rocks are HREE-rich quasi-aluminousperaluminous calc-alkaline-shoshonite series with minor europium anomalies, abundant LILEs and obvious negative anomalies in $\mathrm{Nb}$, Ta and $\mathrm{Ti}$, suggesting that a A'Rongqi-Zalantun continental margin arc existed in the Early Paleozoic. This margin arc may have been produced by the subduction, accretion and soft collisions of the plates along the eastern margin of the Ergun Massif in the Early Paleozoic.

Supplementary Materials: The following supporting information can be downloaded at: https: / / www.mdpi.com/article/10.3390/min12020197/s1, Table S1: LA-ICP-MS U-Pb date of zircons for Late Cambrian-Late Silurian volcanic rocks in Arong Qi; Table S2: Majore element (\%) and trace element $\left(\times 10^{-6}\right)$ analys for Late Cambrian-Late Silurian volcanic rocks in Arong Qi. 


\begin{abstract}
Author Contributions: Conceptualization, D.W. and Z.L.; methodology, J.L.; software, J.X.; validation, D.W. and Z.L.; formal analysis, J.L.; investigation, J.X. and G.S.; resources, G.S.; data curation, J.L.; writing—original draft preparation, D.W.; writing—review and editing, D.W.; visualization, J.X.; supervision, G.S.; project administration, Z.L.; funding acquisition, Z.L. All authors have read and agreed to the published version of the manuscript.
\end{abstract}

Funding: This research was funded by China Geological Survey (grant number DD20160047-08).

Data Availability Statement: The data presented in this study are available in the Supplementary Materials Documents.

Acknowledgments: I cannot thank Zhou Yongheng (senior engineer from Shenyang Center of China Geological Survey) enough for his support. Sun Wei and Xu Fengming from the Shenyang Center were also always helpful by offering their patient guidance. I am also grateful to the review panel for their professional advice on revising and further improving this paper.

Conflicts of Interest: The authors declare no conflict of interest.

\title{
References
}

1. Hong, D.; Wang, S.; Xie, X.; Zhang, J.; Wang, T. Metallogenic Province Derived from Mantle Sources: A Case Study of Central Asian Orogenic Belt. Min. Depos. 2003, 22, 41-55.

2. Li, J. Permian geodynamic setting of Northeast China and adjacent regions: Closure of the Paleo-Asian Ocean and subduction of the Paleo-Pacific Plate. J. Asian Earth Sci. 2006, 26, 207-224. [CrossRef]

3. Li, J.; Gao, L.; Sun, G.; Li, Y.; Wang, Y. Shuangjinzi middle Triassic syn-collisional crust-derived granite in the east Mongolia and its constraint on the timing of collision between Siberian and Sino-Korean paleo-plate. Acta Petrol. Sin. 2007, 23, 565-582.

4. Sun, D.; Wu, F.; Zhang, Y.; Gao, S. The Final Closing Time of the West Lamulun River-Changchun-Yanji Plate Suture Zone: Evidence from the Dayushan Granitic Pluton, Jilin Province. J. Jiling Univ. (Earth Sci. Ed.) 2004, 34, $174-181$.

5. Sun, W.; Chi, X.; Pan, S.; Zhang, X.; Quan, J.; Fan, L.; Wang, L. Zircon LA-ICP-MS U-Pb dating and its geological signifificance of the Dawangzi formation from Wolegen Group in Xinlin area, northern Great Xing'an range. J. Jilin Univ. (Earth Sci. Ed.) 2014, 44, 176-185.

6. Wu, G.; Sun, F.; Zhao, C.; Li, Z.; Zhao, A.; Pang, Q.; Li, G. Discovery of the Early Paleozoic post-collisional granites in northern margin of the Erguna massif and its geological significance. Chin. Sci. Bull. 2005, 50, 2733-2743. [CrossRef]

7. Xu, B.; Chen, B. Framework and evolution of the Middle Paleozoic orogenic belt between Siberian and North China plates in northern Inner Mongolia. Sci. China (Ser. D) 1997, 40, 463-469. [CrossRef]

8. Zhang, L.; Liu, Y.; Li, W.; Han, G.; Zhang, J.; Guo, Q. Discussion on the basement properties and east boundary of the Ergun massif. Sci. Geol. Sin. 2013, 48, 227-244.

9. Zhang, Y.; Zhang, C.; Wu, X.; Cui, T.; Yang, Y.; Chen, H.; Jiang, B.; Guo, W.; Ma, Y. Geochronology and Geochemistry of Late Paleozoic Marine Volcanic from the Zhalantun Area in Northern DaHinggan Mountains and Its Geological Significance. Acta Geol. Sin. 2016, 90, 2706-2720.

10. Li, Y.; Xu, W.-L.; Tang, J.; Pei, F.-P.; Wang, F.; Sun, C.-Y. Geochronology and geochemistry of Mesozoic intrusive rocks in the Xing'an Massif of NE China: Implications for the evolution and spatial extent of the Mongol-Okhotsk tectonic regime. Lithos 2018, 304, 57-73. [CrossRef]

11. Li, Y.; Xu, W.-L.; Zhu, R.-X.; Wang, F.; Ge, W.-C. Sorokin AA Late Jurassic to early Early Cretaceous tectonic nature on the NE Asian continental margin: Constraints from Mesozoic accretionary complexes. Earth-Sci. Rev. 2020, 200, 103042. [CrossRef]

12. Tang, J.; Xu, W.; Li, Y.; Sun, C. Composition variations of Mesozoic and Cenozoic basalts in northern Great Xing'an Range: Implications for thermal evulution of mantle. Earth Sci. 2019, 44, 1096-1112.

13. Tang, J.; Xu, W.; Wang, F.; Ge, W. Subduction history of the Paleo-Pacific slab beneath Eurasian continent: Mesozoic-Paleogene magmatic records in Northeast Asia. Sci. China-Earth Sci. 2018, 61, 527-559. [CrossRef]

14. Tang, J.; Xu, W.; Wang, F.; Zhao, S.; Wang, W. Early Mesozoic southward subduction history of the Mongol-Okhotsk oceanic plate: Evidence from geochronology and geochemistry of EarlyMesozoic intrusive rocks in the Erguna Massif, NE China. Gondwana Res. 2016, 31, 218-240. [CrossRef]

15. Xu, W.; Pei, F.; Wang, F.; Meng, E.; Ji, W.; Yang, D.; Wang, W. Spatial-temporal relationships of Mesozoic volcanic rocks in NE China: Constraints on tectonic overprinting and transformations between multiple tectonic regimes. J. Asian Earth Sci. 2013, 74, 167-193. [CrossRef]

16. Li, Y.; Xu, W.; Wang, F.; Tang, J.; Sun, C.; Wang, Z. Early-Middle Ordovician volcanism along the eastern margin of the Xing'an Massif, Northeast China: Constraints on the suture location between the Xing'an and Songnen-Zhangguangcai Range massifs. Int. Geol. Rev. 2018, 60, 2046-2062. [CrossRef]

17. Liu, Y.; Li, W.; Feng, Z.; Wen, Q.; Neubauer, F.; Liang, C. A review of the Paleozoic tectonics in the eastern part of Central Asian Orogenic Belt. Gondwana Res. 2017, 43, 123-148. [CrossRef]

18. Wu, G.; Chen, Y.; Sun, F.; Liu, J.; Wang, G.; Xu, B. Geochronology, geochemistry, and Sr-Nd-Hf isotopes of the early Paleozoic igneous rocks in the Duobaoshan area, NE China, and their geological significance. J. Asian Earth Sci. 2015, 97, 229-250. [CrossRef] 
19. Miao, L.; Liu, D.; Zhang, F.; Fan, W.; Shi, Y.; Xie, H. Zircon SHRIMP U-Pb ages of the "Xinghuadukou Group" in Hanjiayuanzi and Xinlin areas and the "Zhalantun Group" in Inner Mongolia, Da Hinggan Mountains. Chin. Sci. Bull. 2007, 52, 1112-1124. [CrossRef]

20. Jian, P.; Liu, D.; Kröner, A.; Windley, B.F.; Shi, Y.; Zhang, F.; Shi, G.; Miao, L.; Zhang, W.; Zhang, Q.; et al. Time scale of an early to mid-Paleozoic orogenic cycle of the long-lived Central Asian Orogenic Belt, Inner Mongolia of China: Implications for continental growth. Lithos 2008, 101, 233-259. [CrossRef]

21. Miao, L.; Fan, W.; Liu, D.; Zhang, F.; Shi, Y.; Guo, F. Geochronology and geochemistry of the Hegenshan ophiolitic complex: Implications for late-stage tectonic evolution of the Inner Mongolia-Daxinganling Orogenic Belt, China. J. Asian Earth Sci. 2008, 32, 348-370. [CrossRef]

22. Wu, F.Y.; Jahn, B.M.; Wilde, S.A.; Lo, C.H.; Yui, T.F.; Lin, Q.; Ge, W.C.; Sun, D.Y. Highly fractionated I-type granites in NE China (I): Geochronology and petrogenesis. Lithos 2003, 66, 241-273. [CrossRef]

23. Wu, Y.; Zheng, Y. Genesis of zircon and its constraints on interpretation of U-Pb age. Chin. Sci. Bull. 2004, 49, 1554-1569. [CrossRef]

24. Zorin, Y.A. Geodynamics of the western part of the Mongolia-Okhotsk collisional belt Trans-Baikal region (Russia) and Mongolia. Tectonophysics. 1999, 306, 33-56. [CrossRef]

25. Song, B.; Zhang, Y.; Liu, D. Introduction to the Naissance of SHRIMP and its Contribution to Isotope Geology. J. Chin. Mass Spectrom. Soc. 2002, 23, 58-62.

26. Andersen, T. Correction of common lead in U-Pb analyses that do not report Pb204. Chem. Geol. 2002, 192, 59-79. [CrossRef]

27. Fan, C.; Hu, M.; Zhao, L.; Sun, D.; Zhan, X. Advances in in situ Microanalysis of U-Pb Zircon Geochronology Using Laser Ablation-Inductively Coupled Plasma-Mass Spectrometry. Rock Min. Anal. 2012, 31, $29-46$.

28. Gehrels, G.; Johnsson, M.; Howell, D. Detrital zircon geochronology of the Adams Argillite and Nation River Formation, East-Central Alaska, U.S.A. J. Sediment. Res. 1999, 69, 135-144. [CrossRef]

29. Kalsbeek, F.; Frei, D.; Affaton, P. Constraints on provenance, stratigraphic correlation and structural context of the Volta basin, Ghana, from detrital zircon geochronology: An Amazonian connection? Sediment. Geol. 2008, 212, 86-95. [CrossRef]

30. Nelson, J.; Gehrels, G. Detrital zircon geochronology and provenance of the southeastern Yukon-Tanana terrane. Can. J. Earth Sci. 2007, 44, 297-316. [CrossRef]

31. Sircombe, K. Tracing provenance through the isotope ages of littoral and sedimentary detrital zircon, eastern Australia. Sediment. Geol. 1999, 124, 47-67. [CrossRef]

32. Wu, F.Y.; Sun, D.Y.; Jahn, B.M.; Wilde, S.A. Jurassic garnet-bearing granitic pluton from NE China showing tetrad REE patterns. J. Asian Earth Sci. 2004, 23, 731-744. [CrossRef]

33. Pearce, J.A.; Harris, N.B.W.; Tindle, A.G. Trace element diserimination diagrams for the tectonic interpretation of granitic rocks. J. Petrol. 1984, 25, 956-983. [CrossRef]

34. Winchester, J.A.; Floyd, P.A. Geochemical magma type discrimination: Application to altered and metamorphosed basic igneous rocks. Earth Planet. Sci. Lett. 1976, 28, 459-469. [CrossRef]

35. Hastie, A.R.; Kerr, A.C.; Pearce, J.A.; Mitchell, S.F. Classification of altered volcanic island arc rocks using immobile trace elements: Development of the Th-Co discrimination diagram. J. Petrol. 2007, 48, 2341-2357. [CrossRef]

36. Wilson, M. Igneous Petrogenesis: A Global Tectonic Approach; Chapman and Hall: London, UK, 1989; p. 466.

37. Sun, S.; Mcdonough, W. Chemical and Isotopic Systematics of Oceanic Basalts: Implications for Mantle Composition and Processes; Geological Society of London Special Publications: London, UK, 1989; pp. 313-345.

38. Sun, W.; Chi, X.-G.; Zhao, Z.; Pan, S.-Y.; Liu, J.-F.; Zhang, R.; Quan, J.-Y. Zircon geochronology constraints on the age and nature of 'Precambrian metamorphic rocks' in the Xing'an block of Northeast China. Int. Geol. Rev. 2014, 56, 672-694. [CrossRef]

39. Chen, L.; Zhao, Z.F. Origin of continental arc andesites: The composition of source rocks is the key. J. Asian Earth Sci. 2017, 145, 217-232. [CrossRef]

40. Guffanti, M.; Clynne, M.A.; Muffler, L.J.P. Thermal and mass implications of magmatic evolution in the Lassen volcanic region, California, and minimum constraints on basalt influx to the lower crust. J. Geophys. Res. Solid Earth 1996, 101, 3003-3013. [CrossRef]

41. Jung SHoernes, S.; Mezger, K. Synorogenic melting of mafic lower crust: Constraints from geochronology, petrology and Sr, $\mathrm{Nd}, \mathrm{Pb}$ and, $\mathrm{O}$ isotope geochemistry of quartz diorites (Damara orogen, Namibia). Contrib. Mineral. Petrol. 2002, 143, 551-566. [CrossRef]

42. Petford, N.; Atherton, M. Na-rich partial melts from newly underplated basaltic crust: The Cordillera Blanca Batholith, Peru. J. Petrol. 1996, 37, 1491-1521. [CrossRef]

43. Bonin, B. Do coeval mafic and felsic magmas in post-collisional to within-plate regimes necessarily imply two contrasting, mantle and crustal, sources? A review. Lithos 2004, 78, 1-24. [CrossRef]

44. Lee, C.T.A.; Lee, T.C.; Wu, C.T. Modeling the compositional evolution of recharging, evacuating, and fractionating (REFC) magma chambers: Implications for differentiation of arc magmas. Geochim. Cosmochim. Acta 2014, 143, 8-22. [CrossRef]

45. Guo, F.; Nakamuru, E.; Fan, W.M.; Kobayoshi, K.; Li, C.W. Generation of Palaeocene adakitic andesites by magma mixing in Yanji area, NE China. J. Petrol. 2007, 48, 661-692. [CrossRef]

46. Reubi, O.; Blundy, J. A dearth of intermediate melts at subduction zone volcanoes and the petrogenesis of arc andesites. Nature 2009, 461, 1269-1273. [CrossRef] 
47. Dong, Y.; Ge, W.C.; Yang, H.; Xu, W.L.; Zhang, Y.L.; Bi, J.H.; Liu, X.W. Geochronology geochemistry and Hf isotopes of Jurassic intermediate-acidic intrusions in the Xing'an Block, northeastern China: Petrogenesis and implications for subduction of the Paleo- Pacific oceanic plate. J. Asian Earth Sci. 2016, 118, 11-31. [CrossRef]

48. Kelemen, P.B. Genesis of high Mg\# andesites and the continental crust. Contrib. Mineral. Petrol. 1995, 120, 1-19.

49. Yu, Q.; Ge, W.C.; Zhang, J.; Zhao, G.C.; Zhang, Y.L.; Yang, H. Geochronology, petrogenesis and tectonic implication of Late Paleozoic volcanic rocks from the Dashizhai Formation in Inner Mongolia, NE China. Gondwana Res. 2017, 43, 164-177. [CrossRef]

50. Taylor, S.; Mclennan, S. The continental crust: Its composition and evolution. J. Geol. 1985, 94, 57-72.

51. Weaver, B.; Tarney, J. Empirical-Approach to Estimating the Composition of the Continental-Crust. Nature 1984, $310,575-577$. [CrossRef]

52. Rudnick, R.; Shan, G.; Ling, W.; Liu, Y.; McDonough, W. Petrology and geochemistry of spinel peridotite xenoliths from Hannuoba and Qixia, North China craton. Lithos 2004, 77, 609-637. [CrossRef]

53. Rollinson, H. Using Geochemical Data:Evaluation, Presentation, Interpretation; Longman Scientific and Technical Limited: New York, NY, USA, 1993; pp. 1-343.

54. Kelemen, P.B.; Whitehead, J.A.; Aharonov, E.; Jordahl, K.A. Experiments on flow focusing in soluble porous media, with applications to melt extraction from the mantle. J. Geophys. Res. Solid Earth 1995, 100, 475-496. [CrossRef]

55. Spera, F.J.; Bohrson, W.A. Energy-Constrained Open-System Magmatic Processes I: General Model and Energy-Constrained Assimilation and Fractional Crystallization (EC-AFC) Formulation. J. Petrol. 2021, 20, 999-1018. [CrossRef]

56. Zhang, Z.C.; Chen, Y.; Li, K.; Li, J.F.; Yang, J.F.; Qian, X.Y. Geochronology and geochemistry of Permian bimodal volcanic rocks from central Inner Mongolia, China: Implications for the Late Palaeozoic tectonic evolution of the south-eastern Central Asian Orogenic Belt. J. Asian Earth Sci. 2017, 135, 370-389. [CrossRef]

57. Defant, M.J. Drummond, M.S. Derivation of some modern arc magmas by melting of young subducted lithosphere. Nature 1990, 347, 662-665. [CrossRef]

58. Jahn, B.M.; Wu, F.; Lo, C.H.; Tsai, C.H. Crust-mantle interaction induced by deep subduction of the continental crust: Geochemical and sr-nd isotopic evidence from post-collisional mafic-ultramafic intrusions of the northern dabie complex, central china. Chem. Geol. 1999, 157, 119-146. [CrossRef]

59. Pearce, J.A. Geochemical fingerprinting of oceanic basalts with applications to ophiolite classification and the search for Archean oceanic crust. Lithos 2008, 100, 14-48. [CrossRef]

60. Sun, W. Zircon Geochronology Constraints on the Age and Nature of "Precambrian Metamorphic rocks" and Lower Paleozoic in the Xing'an Block of Northeast China; Jilin University: Changchun, China, 2014.

61. Ge, W.; Wu, F.; Zhou, C.; Zhang, J. Porphyry Cu-Mo deposits in the eastern Xing'an-Mongolian Orogenic Belt: Mineralization ages and their geodynamic implications. Chin. Sci. Bull. 2007, 52, 3416-3427. [CrossRef]

62. Han, G.; Liu, Y.; Neubauer, F.; Genser, J.; Li, W.; Zhao, Y.; Liang, C. Origin of terranes in the eastern Central Asian Orogenic Belt, NE China: U-Pb ages of detrital zircons from Ordovician-Devonian sandstones, North Da Xing'an Mts. Tectonophysics 2011, 511, 109-124. [CrossRef]

63. Yang, X. Geological Characteristics and Study of Detrital Zircon Geochronology of Epimetamorphic Rock Series in Zhalantun Area; Jilin University: Changchun, China, 2007; pp. 1-166.

64. Cui, G.; Wang, J.; Zhang, J.; Cui, G. U-Pb SHRIMP dating of zircons from Duobaoshan granodiorite in Heilongjiang and its geological significance. World Geol. 2008, 27, 387-394.

65. She, H.; Li, J.; Xiang, A.; Guan, J.; Yang, Y.; Zhang, D.; Tan, G.; Zhang, B. U-Pb ages of the zircons from primary rocks in middle-northern Daxinganling and its implications to geotectonic evolution. Acta Petrol. Sin. 2012, 28, 571-594.

66. Wu, F.; Sun, D.; Ge, W.; Zhang, Y.; Grant, M.L.; Wilde, S.A.; Jahn, B.M. Geochronology of the Phanerozoic granitoids in northeastern China. J. Asian Earth Sci. 2011, 41, 1-30. [CrossRef] 